Konsep Pembelajaran Kontekstual, Oleh: Hamam

\title{
KONSEP PEMBELAJARAN KONTEKSTUAL DALAM TEORI DAN PRAKTIK
}

\author{
Hamam $^{*}$
}

\begin{abstract}
Abstrak
Peningkatan pembelajaran di sekolah banyak ditentukan oleh kreatifitas pendidik, karena pendidik merupakan ujung tombak dalam upaya mencetak sumber daya manusia berkualitas dan berdedikasi tinggi, oleh sebab itu guru dituntut untuk melakukan inovasi dalam pembelajaran. Salah satu inovasi pembelajaran yang perlu diterapkan adalah pembelajaran kontekstual. Penerapan pembelajaran kontekstual disebabkan ole h: (1) sebagian besar waktu belajar sehari-hari di sekolah masih didominasi kegiatan penyampaian pengetahuan oleh guru, sementara siswa "dipaksa" memperhatikan dan menerimanya, (2) materi pembelajaran bersifat abstrakteoritis-akademis, tidak terkait dengan masalah-masalah yang dihadapi siswa sehari-hari di lingkungan keluarga, masyarakat, alam sekitar dan dunia kerja.(3) penilaian hanya dilakukan dengan tes yang menekankan pengetahuan, tidak menilai kualitas dan kemampuan belajar siswa yang autentik pada situasi yang autentik. (4) sumber belajar masih terfokus pada guru dan buku, lingkungan sekitar belum dimanfaatkan secara optimal
\end{abstract}

Kata Kunci: Pembelajaran, Kontekstual

\section{Pendahuluan}

Pembelajaran kontekstual atau lebih dikenal dengan CTL (Contextual Teaching and Learning) sebenarnya bukan hal baru, tetapi CTL dewasa ini sangat ditekankan karena perkembangan dunia kerja di jaman global yang ditandai dengan persaingan bebas, sehingga sekolah harus menyusun ulang kurikulumnya untuk menyesuaikan

* Dosen Institut Agama Islam Tribakti (IAIT) Kediri, DPK IAIN Sunan Ampel Surabaya.

Vol. 22 Nomor. 2 Juli 2011 
dengan tuntutan global tersebut. Pada awalnya, CTL lebih banyak digunakan pada sekolah-sekolah kejuruan, kemudian digunakan di sekolah umum tetapi untuk anak-anak dengan kemampuan dibawah ratarata. Kemudian, ketika CTL digunakan untuk belajar konsepkonsep/akademis, CTL digunakan dalam bentuk watered-down dari konsep-konsep abstrak yang harus dipelajari dengan sedikit contohcontoh penggunaan di dunia nyata. Sekarang CTL digunakan dalam kurikulum, termasuk KBK dan KTSP yang menegaskan bahwa proses belajar mengajar harus berbasis CTL

Pembelajaran kontekstual merupakan pembelajaran yang mengkaitkan materi pembelajaran dengan konteks dunia nyata yang dihadapi siswa sehari-hari baik dalam lingkungan keluarga, masyarakat, alam sekitar dan dunia kerja, sehingga siswa mampu membuat hubungan antara pengetahuan yang dimilikinya dengan penerapannya dalam kehidupan sehari-hari, dengan melibatkan tujuh komponen utama pembelajaran yakni: kontruktivisme (constructivism), bertanya (questioning), menyelidiki (inquiry), masyarakat belajar (learning community), pemodelan (modeling), refleksi (reflection), dan penilaian autentik (authentic assessment).

Makna dari kontruktivisme adalah siswa mengkonstruksi/ membangun pemahaman mereka sendiri dari pengalaman baru berdasar pada pengetahuan awal melalui proses interaksi sosial dan asimilasi-akomodasi. Implikasinya adalah pembela-jaran harus dikemas menjadi proses "mengkonstruksi" bukan menerima pengetahuan. Inti dari inquiry atau menyelidiki adalah proses perpindahan dari pengamatan menjadi pemahaman. Oleh karena itu dalam kegiatan ini siswa belajar menggunakan keterampilan berpikir kritis. Bertanya atau questioning dalam pembelajaran kontekstual dilakukan baik oleh guru maupun siswa. Guru bertanya dimaksudkan untuk mendorong, membimbing dan menilai kemampuan berpikir siswa. Sedangkan untuk siswa bertanya merupakan bagian penting dalam pembelajaran yang berbasis inquiry. Masyarakat belajar merupakan sekelompok orang (siswa) yang terikat dalam kegiatan belajar, tukar pengalaman, dan berbagi pengalaman. Sesuai dengan teori kontruktivisme, melalui interaksi sosial dalam masyarakat belajar ini maka siswa akan mendapat kesempatan untuk mengkonstruksi pengetahuannya sendiri, oleh karena itu bekerjasama 
dengan orang lain lebih baik daripada belajar sendiri. Pemodelan merupakan proses penampilan suatu contoh agar orang lain (siswa) meniru, berlatih, menerapkan pada situasi lain, dan mengembangkan-nya. Menurut Albert Bandura, belajar dapat dilakukan dengan cara pemodelan ini. Penilaian autentik dimaksudkan untuk mengukur dan membuat keputusan tentang pengetahuan dan keterampilan siswa yang autentik (senyatanya). Agar dapat menilai senyatanya, penilaian autentik dilakukan dengan berbagai cara misalnya penilaian penilaian produk, penilaian kinerja (performance), portofolio, tugas yang relevan dan kontekstual, penilaian diri, penilaian sejawat dan sebagainya. Refleksi pada prinsipnya adalah berpikir tentang apa yang telah dipikir atau dipelajari, dengan kata lain merupakan evaluasi dan instropeksi terhadap kegiatan belajar yang telah ia lakukan.

Alasan perlu diterapkannya pembelajaran kontekstual adalah : (1) Sebagian besar waktu belajar sehari-hari di sekolah masih didominasi kegiatan penyampaian pengetahuan oleh guru,sementara siswa "dipaksa"memperhatikan dan menerima-nya, sehingga tidak menyenangkan dan memberdayakan siswa. (2) Materi pembelajaran bersifat abstrak-teoritis-akademis, tidak terkait dengan masalah-masalah yang dihadapi siswa sehari-hari di lingkungan keluarga, masyarakat, alam sekitar dan dunia kerja. (3) Penilaian hanya dilakukan dengan tes yang menekankan pengetahuan, tidak menilai kualitas dan kemampuan belajar siswa yang autentik pada situasi yang autentik. (4) Sumber belajar masih terfokus pada guru dan buku. Lingkungan sekitar belum dimanfaatkan secara optimal.

Landasan filosofi pembelajaran kontekstual adalah konstruktivisme yang menyatakan bahwa pengetahuan tidak dapat ditransfer dari guru ke siswa seperti halnya mengisi botol kosong, sebab otak siswa tidak kosong melainkan sudah berisi pengetahuan hasil pengalaman-pengalaman sebelumnya.Siswa tidak hanya "menerima" pengetahuan, namun "mengkonstruksi" sendiri pengetahuannya melalui proses intra-individual (asimilasi dan akomodasi) dan inter-individual (interaksi sosial).

Pembelajaran kontekstual sebenarnya bukam merupakan pendekatan yang sama sekali baru. Dasar pembelajaran kontekstual sudah dikembangkan oleh John Dewey sejak tahun 1916. Pendekatan ini 
kemudian digali kembali, dikembangkan lagi, dan dipopulerkan oleh The Washington State Concorcium for Contextual Teaching and Learning dengan melibatkan 11 perguruan tinggi, 20 sekolah, dan lembaga-lembaga yang bergerak dalam dunia pendidikan di Amerika Serikat.

\section{Konsep Pembelajaran Kontekstual}

Pembelajaran Kontekstual adalah strategi pembelajaran yang menghubungkan antara konten pelajaran dengan situasi kehidupan nyata, dan mendorong siswa mengaitkan antara pengetahuan dan pengalaman yang didapatnya di sekolah dengan kehidupannya sebagai anggota keluarga, warganegara, dan dunia kerja. ${ }^{1}$

Pembelajaran Kontekstual merupakan respons dari ketidak puasan praktek pembelajaran yang sangat menekankan pada pengetahuan abstrak atau konseptual semata-mata. Pembelajaran demikian memang cocok untuk melahirkan para akademisi, tetapi tidak menyiapkan siswa untuk menjadi seorang professional; dengan kata lain, pembelajaran yang terlampau abstrak telah mengabaikan aspek kontekstual atau terapan dari pengetahuan tersebut.

Bagi siswa, proses pembelajaran tradisional yang menekankan pada pengetahuan abstrak/konseptual lebih pasif daripada pembelajaran yang kontekstual. Pada proses pembelajaran tradisional tersebut, siswa diharapkan untuk memahami dan menyusun informasi dalam pikirannya melalui kegiatan mendengarkan guru dan membaca materi yang ditugaskan. Sesuai dengan itu, maka metode pengajaran lebih berpusat pada guru

Tidak semua siswa memiliki kemampuan untuk menyerap informasi secara abstrak, oleh karena itu banyak siswa yang mengalami kesulitan dalam belajar. Juga banyak yang lulus sekolah tetapi tidak mampu berada di masyarakat sebagai anggota yang bermutu.

Penguasaan terhadap pengetahuan faktual atau 'a need-to-know basis' masih tetap diperlukan sebagai landasan pengembangan ilmu pengetahuan, tetapi pengetahuan itu lebih mudah untuk dipahami jika diperoleh dari pengalaman langsung, daripada siswa hanya menghafal dan menyimpan informasi itu dalam pikirannya sampai suatu saat nanti diperlukan.

${ }^{1}$ Nurhadi, dkk., Kontekstual dan Penerapannya dalam KBK, (Malang: Penerbit Universitas Negeri Malang, 2004), h. 4 
Apprenticeship (belajar untuk mencapai keahlian tertentu, magang) adalah suatu metode pembelajaran yang menghubung-kan pembelajaran dengan dunia nyata (Bond, 2005). Dalam Pembelajaran Kontekstual pembelajaran konsep-konsep abstrak dilakukan dengan prinsip-prinsip apprenticeship tersebut. Karena yang dipelajari adalah konsep (yang lebih berkaitan dengan kognisi daripada keterampilan, maka pembelajarannya disebut dengan cognitive apprenticeship.

Cognitive apprenticeship adalah suatu metode melatih siswa dalam menyelesaikan suatu tugas. Ada tiga hal utama yang harus dilakukan guru sebelum pembelajaran dilakukan, yaitu: (1) terlebih dahulu menetapkan kompetensi yang harus dicapai siswa, (2) menunjukkan manfaat dari tugas yang diberikan, dan (3) memberi peluang untuk keberagaman cara belajar siswa.

Dalam cognitive apprenticeship, dilakukan visualisasi konsep-konsep abstrak, memahami konsep, dan menggunakan-nya untuk menyelesaikan tugas yang diberikan. Terkait dengan konsep keberagaman tersebut, dalam CTL perlu dilakukan diversified learning strategies, yaitu yaitu penggunaan strategi pembelajaran yang bervariasi namun kontekstual. Metode ceramah dalam beberapa hal masih diperlukan, tetapi metode-metode yang berpusat pada siswa (studentcentered) seperti metode inkuiri dan metode kooperatif akan lebih membantu siswa mengembangkan kompetensi dengan baik. Begitu juga, perlu dilakukan differentiated teaching strategies, yaitu pembelajaran yang demokratis dimana siswa mendapat peluang yang luas untuk memahami informasi sesuai dengan kecenderungan yang dimiliki masing-masing. Disini kita diingatkan dengan konsep multiple intelligence dari Gardner, yang menekankan bahwa setiap individu memiliki kecenderung-an yang dominan dalam dirinya, dan keberhasilan individu tersebut (dalam belajar dan bekerja) besar dipengaruhi oleh apakah dia dapat memanfaatkan kecenderungannya tersebut untuk mengatasi permasalahan-permasalahan yang dihadapi

Pemberdayaan (empowerment) sangat diperlukan dalam Pembelajaran Kontekstual (Bond, 2005). Pemberdayaan siswa dapat dilakukan dengan cara: (1) Fading (menjauh secara pelahan), yaitu dukungan guru dikurangi sedikit demi sedikit hingga akhirnya siswa dapat menyelesaikan tugasnya secara mandiri; (2) Articulation (penyampaian), yaitu kesempatan untuk siswa terlibat dalam 
Konsep Pembelajaran Kontekstual, Oleh: Hamam

percakapan atau diskusi mengenai pengetahuannya dalam rangka memecahkan masalah; (3) Reflection (refleksi, melihat kediri-sendiri), yaitu kegiatan dimana siswa dapat membandingkan kemampuan dan keterampilannya dengan ahli di bidangnya; dan (4) Exploration (eksplorasi, berkarya), yaitu saat dimana guru mendorong siswa untuk mencoba menemukan dan memecahkan persoalan secara mandiri

\section{Model dan Strategi Pembelajaran Kontekstual}

\section{Model Pembelajaran Kontekstual}

Beberapa model pembelajaran yang merupakan aplikasi pembelajaran kontekstual antara lain model pembelajaran langsung (direct instruction), pembelajaran koperatif (cooperative learning), pembelajaran berbasis masalah (problem based learning).

\section{a. Model Pembelajaran Langsung}

Inti dari model pembelajaran langsung adalah guru mendemonstrasikan pengetahuan atau keteram-pilan tertentu, selanjutnya melatihkan keterampilan tersebut selangkah demi selangkah kepada siswa.

Rasional teoritik yang melandasi model ini adalah teori pemodelan tingkah laku yang dikembangkan oleh Albert Bandura. Menurut Bandura, belajar dapat dilakukan melalui pemodelan (mencontoh, meniru) perilaku dan pengalaman orang lain. Sebagai contoh untuk dapat mengukur panjang dengan jangka sorong, siswa dapat belajar dengan menirukan cara mengukur panjang dengan jangka sorong yang dicontohkan oleh guru.

Tujuan yang dapat dicapai melalui model pembelajaran ini terutama adalah penguasaan pengetahuan prosedural (pengetahuan bagaimana melakukan sesuatu misalnya mengukur panjang dengan jangka sorong, mengerjakan soal-soal yang terkait dengan hukum kekekalan energi, dan menimbang benda dengan neraca Ohauss), dan atau pengetahuan deklaratif (pengetahuan tentang sesuatu misal namanama bagian jangka sorong, pembagian skala nonius pada micrometer sekrup, dan fungsi bagian-bagian neraca Ohauss), serta keterampilan belajar siswa (misal menggaris bawahi kata kunci, menyusun jembatan keledai, membuat peta konsep, dan membuat rangkuman).

Model pembelajaran ini cenderung berpusat pada guru, 
sehingga sebagian besar siswa cenderung bersikap pasif, maka perencanaan dan pelaksanaan hendaknya sangat hati-hati. Sistem pengelolaan permbelajaran yang dilakukan oleh guru harus menjamin keterlibatan seluruh siswa khususnya dalam memperhatikan, mendengarkan, dan resitasi (tanya jawab). Pengaturan lingkungan mengacu pada tugas dan memberi harapan yang tinggi agar siswa dapat mencapai tujuan pembelajaran

\section{b. Model Pembelajaran Berbasis Masalah}

Inti dari pembelajaran berbasis masalah adalah guru menghadapkan siswa pada situasi masalah kehidupan nyata (autentik) dan bermakna, memfasilitasi siswa untuk memecahkannya melalui penyelidikan/ inkuari dan kerjasama, memfasilitasi dialog dari berbagai segi, merangsang siswa untuk menghasilkan karya pemecahan dan peragaan hasil.

Rasional teoritik yang melandasi model ini adalah teori konstruktivisme Piaget dan Vigotsky, serta teori belajar penemuan dari Bruner. Menurut teori konstruktivisme pengetahuan tidak dapat ditransfer dari guru ke siswa seperti menuangkan air dalam gelas, tetapi siswa mengkonstruksi sendiri pengeta-huannya melalui proses intra-individual asimilasi dan akomodasi (menurut Piaget) dan proses inter-individual atau sosial (menurut Vigotsky).Menurut Bruner belajar yang sebenarnya terjadi melalui penemuan, sehingga dalam proses pembelajaran hendaknya banyak mencip-takan peluang-peluang untuk aktivitas penemuan siswa.

Tujuan yang dapat dikembangkan melalui model pembelajaran ini adalah keterampilan berfikir dan pemecahan masalah, kinerja dalam menghadapi situasi kehidupan nyata, membentuk pebelajar yang otonom dan mandiri

\section{c. Model Pembelajaran Koperatif}

Inti model pembelajaran koperatif adalah siswa belajar dalam kelompok-kelompok kecil, yang anggota-anggotanya memeliki tingkat kemampuan yang berbeda (heterogen). Dalam memahami suatu bahan pelajaran dan menyelesaikan tugas kelompok, setiap anggota saling bekerjasama sampai seluruh anggota menguasai bahan pelajaran tersebut.

Dalam variasinya ditemui banyak tipe pendekatan 
pembelajaran koperatif misalnya STAD (Student Teams Achievement Division), Jigsaw, Investigasi Kelompok, dan Pendekatan Struktural, namun tidak dikemukakan dalam materi diklat ini.

Rasional teoritik yang melandasi model ini adalah teori konstruktivisme Vigotsky yang menekankan pentingnya sosiokultural dalam proses belajar seperti tersebut di muka, dan teori pedagogi John Dewey yang menyatakan bahwa kelas seharusnya merupakan miniatur masyarakat dan berfungsi sebagai laboratorium untuk belajar kehidupan nyata. Guru seharusnya menciptakan di dalam lingkungan belajarnya suatu sistem sosial yang bercirikan demokrasi dan proses ilmiah.

Tujuan yang dapat dicapai melalui model pembelajaran ini adalah hasil belajar akademik yakni penguasaan konsep-konsep yang sulit, yang melalui kelompok koperatif lebih mudah dipahami karena adanya tutor teman sebaya, yang mempunya orientasi dan bahasa yang sama. Disamping itu hasil belajar keterampilan sosial yang berupa keterampilan koperatif (kerjasama dan kolaborasi) juga dapat dikembangkan melalui model pembelajaran ini

\section{Strategi Pembelajaran Kontekstual}

Texas Collaborative for Teaching Excellence (2005) mengajukan suatu strategi dalam melakukan pembelajaran kontekstual yang diakronimkan menjadi REACT, yaitu: relating, experiencing, applying, cooperating, dan transferring.

a. Relating: yaitu belajar dalam konteks menghubungkan apa yang hendak dipelajari dengan pengalaman atau kehidupan nyata. Untuk itu, bawa perhatian siswa pada pengalaman, kejadian, dan kondisi sehari-hari. Lalu, hubungkan/kaitkan hal itu dengan pokok bahasan baru yang akan diajarkan.

b. Experiencing: yaitu belajar dalam konteks eksplorasi, mencari, dan menemukan sendiri. Memang, pengalaman itu dapat diganti dengan video, atau bacaan (dan bahkan kelihatannya dengan cara ini belajar bisa lebih cepat), tetapi strategi demikian merupakan strategi pasif, artinya, siswa tidak secara aktif/langsung mengalaminya.

c. Applying: yaitu belajar mengaplikasikan konsep dan informasi dalam konteks yang bermakna. Belajar dalam konteks ini serupa dengan simulasi, yang seringkali dapat membuat siswa mencita-citakan sesuatu, atau membayangkan suatu tempat bekerja dimasa depan. 
Simulasi seperti bermain peran merupakan contoh yang sangat kontekstual dimana siswa mengaplikasikan pengetahuannya seperti dalam dunia nyata. Seringkali juga dilakukan berupa pengalaman langsung (firsthand experience) seperti magang.

d. Cooperating: yaitu proses belajar dimana siswa belajar berbagi (sharing) dan berkomunikasi dengan siswa lain. Pembelajaran kooperatif merupakan salahsatu strategi utama dalam Pembelajaran Kontekstual, karena pada kenyataannya, karyawan berhasil adalah yang mampu berkomunikasi secara efektif dan bisa bekerja dengan baik dalam tim. Aktivitas belajar yang relevan dengan pembelajaran kooperatif adalah kerja kelompok; dan kesuksesan kelompok tergantung pada kinerja setiap anggotanya. Peer grouping juga suatu aktivitas pembelajaran kooperatif. Beberapa teknik pembelajaran kooperatif akan diulas pada bagian lain dari makalah ini.

e. Transferring: yaitu belajar dalam konteks pengetahuan yang sudah ada, artinya adalah, siswa belajar menggunakan apa yang telah dipelajari untuk menyelesaikan persoalan yang dihadapi. Aktivitas dalam pembelajaran ini antara lain adalah pemecahan masalah (problem solving).

Clifford dan Wilson (2000) menyebutkan bahwa Pembelajaran Kontekstual tercermin dari pembelajaran yang:

a. Berbasis masalah (memecahkan masalah, menemukan dan menjawab masalah)

b. Menggunakan konteks yang beragam (teknik pembelajaran kontekstual yang digunakan harus bervariasi, tidak monoton)

c. Menghargai keberagaman siswa (dari segi kemampuan, bakat, latar belakang, dan lain-lain.)

d. Mendukung pembelajaran mandiri (self-regulated learning)

e. Menggunakan kelompok belajar dengan semangat saling ketergantungan (interdependen, belajar secara kooperatif)

f. Menggunakan asesmen otentik ${ }^{2}$

${ }^{2}$ Clifford, M. and Wilson, M. (2000). 'Professional Learning and Student's Experiences: Lesson Learned from Implementation'. Educational Brief . No. 2 December 2000. Texas Collaborative for Teaching Excellence. (2005). REACT Strategy. Printed on $15^{\text {th }}$ July 2005. h. 20

Vol. 22 Nomor. 2 Juli 2011 
Konsep Pembelajaran Kontekstual, Oleh: Hamam

\section{Penerapan Strategi Pembelajaran Kontekstual}

Pembelajaran Kontekstual berasosiasi pada beberapa konsep antara lain:

a. Pengajaran berbasis masalah adalah sutu pendekatan pengajaran yang menggunakan masalah dunia nyata sebagai suatu konteks bagi siswa untuk belajar dengan cara berpikir kritis dan ketrampilan pemecahan masalah, serta memperoleh pengetahuan dan konsep yang esensian dari materi pelajaran. Ciri-ciri pengajaran berbasis masalah antara lain: (1) Pengajuan pertanyaan atau masalah, (2) Berfokus pada keterkaitan antar disiplin, (3) Penyelidikan Autentik, (4) Menghasilkan produk/karya dan memamerkannya.

b. Pengajaran kooperatif adalah suatu system yang di dalamnya terdapat elemen yang saling terkait. Elemen tersebut adalah (1) saling ketergantungan positif, (2) interaksi tatap muka, (3) akuntabilitas individual, (4) keterampilan untuk menjalin hubungan antar pribadi atau keterampilan social yang secara sengaja diajarkan. Pembelajaran kooperatif dilaksanakan dengan cara:

1) Metode STAD (Student Teams Achievement Divisions) yaitu metode yang digunakan untuk mengajarkan informasi akademik baru kepada siswa setiap minggu, baik melalui penyajian verbal maupun tertulis. Siswa di dalam kelas dibagi menjadi beberapa kelompok atau tim, tiap tim memiliki anggota yang heterogen, baik jenis kelamin, ras, etnik maupun kemampuannya. Tiap anggota tim menggunakan lembar kerja akademik, kemudian tim saling membantu menguasai bahan ajar melalui tanya jawab atau diskusi antar anggota sesama tim.

2) Metode Jigsaw yaitu suatu metode pembelajaran dengan membagi siswa dalam beberapa tim yang terdiri 5 atau 6 siswa dengan karakteristik yang heterogen.

3) Metode GI (Group Investigation) adalah metode yang paling kompleks dan paling sulit untuk dilaksanakan karena dalam metode ini siswadilibatkan sejak perencanaan, baik dalam menentukan topic maupun cara untuk mempelajarinya melalui investigasi. Langkah-langkah metode GI antara lain: (1) seleksi topic, (2) merncanakan kerjasama, (3) implementasi,(4) analisis dan sintesis, (5) penyajian hasil akhir, (6) evaluasi. 
4) Metode Struktural yaitu metode pembelajaran yang menekankan pada struktur khusus yang dirancang untuk mempengaruhi pola interaksi siswa. Struktur tersebut dikembangkan dengan maksud agar menjadi alternative dari berbagai struktur kelas yang lebih tradisional. ${ }^{3}$

c. Pengajaran berbasis Inquiry yaitu pembelajaran penemuan dengan cara siswa didorong untuk belajar sebagian besar melalui keterlibatan aktif mereka sendiri dengan konsep dan prinsip-prinsip, sedangkan guru mendorong siswa untuk memiliki pengalaman dan melakukan percobaan yang memungkinkan mereka menemukan prinsip-prinsip untuk diri sendiri.

d. Pengajaran Autentik yaitu pendekatan pengeajaran yang memperkenankan siswa untuk mempelajari konteks bermakna. Siswa mengembangkan ketrampilan berpikir dan pemecahan masalah yang penting dalam konteks kehidupan nyata.

e. Pengajaran Berbasis Proyek/tugas pendekatan ini memperkenankan siswa untuk bekerja secara mandiri dalam mengkonstruk (membentuk) pembelajarannya, dan mengkulminasikannya dalam produk nyata. Siswa diberikan tugas/proyek yang kompleks, sulit, lengkap, tetapi realistis/autentik kemudian diberikan bantuan secukupnya agar mereka dapat menyelesaikan tugasnya. (Buck Institute for Education, 2001)

f. Pengajaran Berbasis Kerja yaitu pengejaran yang memungkinkan siswa menggunakan konteks tempat kerja untuk mempelajari materi pelajaran berbasis sekolah dan bagaimana materi tersebut digunakan kembali dalam tempat kerja. Jadi dalam hal ini tempat kerja atau sejenisnya dan berbagai aktivitas dipadukan dengan materi pelajaran untuk kepentingan siswa.

g. Pengajaran berbasis jasa layanan yaitu metodologi pengajaran yang mengkombinasikan jasa layanan masyarakat dengan suatu struktur sekolah untuk merefleksikan jasa layanan tersebut; jadi menekankan hubungan antara pengalaman jasa layanan dan pembelajaran akademis. Strategi pembelajaran berpijak pada pemikiran bahwa semua kegiatan kehidupan dijiwai oleh kemampuan melayani. Dalam industri modern, kata kunci yang digunakan adalah layanan yang baik. Untuk itu sejak usia dini siswa dibiasakan untuk melayani orang lain.

\footnotetext{
${ }^{3}$ Nurhadi dkk 2004, h. 64-65
}

Vol. 22 Nomor. 2 Juli 2011 


\section{Model Penilaian Pembelajaran Kontekstual}

Pembelajaran Kontekstual menuntut otentisitas pembelajaran, yaitu bahwa pengalaman belajar yang diperoleh siswa haruslah nyata dan bermakna bagi kehidupan. Karena itu, semua komponen pembelajaran haruslah otentik, mulai dari materi pembelajaran, strategi/metodenya, dan tentunya pula pendekatan asesmennya. Asesmen otentik adalah asesmen yang benar-benar mencerminkan aktivitas nyata dalam kehidupan sehari-hari. Asesmen yang tidak memotret kebutuhan nyata tidak dapat disebut asesmen otentik.

Orientasi baru tersebut telah menempatkan asesmen dalam posisi strategis sekaligus kompleks. Strategis karena pengukuran keberhasilan suatu pembelajaran (baca: sejauhmana kompetensi yang ditargetkan tercapai) sangat ditentukan oleh bagaimana asesmen dilakukan (baca: apakah asesmen yang digunakan memang benar mampu mengukur tingkat kompetensi?). Asesmen berbasis kompetensi juga terbilang kompleks, karena tugasnya memantau proses dan juga produk belajar, karenanya mau tidak mau asesmen harus terpadu dengan pembelajaran (bandingkan dengan penggunaan tes-tes yang dilakukan pada akhir suatu pokok bahasan dan pada akhir semester).

Model penilaian dalam pembelajaran kontekstual menggunakan system penilaian yang disebut Authentic Assesment (Penilaian yang sebenarnya). Prinsip dan ciri yang dipakai dalam penilaian autentik adalah sebagai berikut: (1) Harus mengukur semua aspek pembelajaran: proses, kinerja, dan produk, (2) dilaksanakan selama dan sesudah proses pembelajaran berlangsung, (3) menggunakan berbagai cara dan berbagai sumber, (4) tes hanya salah satu alat pengumpul data penilaian, (5) tugas-tugas yang diberikan kepada siswa harus mencerminkan bagian-bagian kehidupan siswa yang nyata setiap hari, mereka harus dapat menceriterakan pengalaman atau kegiatan yang mereka lakukan setiap hari, (6) penilaian harus menekankan kedalaman pengetahuan dan keahlian siswa, bukan keluasannya (kuantitas).

Assesment adalah proses pengumpulan berbagai data yang bisa memberikan gambaran perkembangan belajar siswa. Gambaran perkembangan belajar siswa perlu diketahui guru agar bisa memastikan bahwa siswa mengalami proses pembelajaran dengan benar. Apabila data yang dikumpulkan guru mengidentifikasikan bahwa siswa mengalami kemacetan dalam belajar maka guru segera bisa mengambil 
tindakan yang tepat agar siswa terbebas dari kemacetan belajar.

Asesmen non-tes dilakukan dalam suasana non-threatening. Bila pada tes terjadi one-time response untuk melihat hasil belajar, maka pada non-tes asesmen dilakukan untuk melihat proses dan hasil belajar. Oleh karenanya, non-tes dilakukan secara terpadu dengan pembelajaran. Asesmen otentik mengandung pengertian pemberian tugas-tugas yang secara langsung bermakna. Misalnya dalam pelajaran membaca. Tugas membaca beberapa naskah tulisan dan membandingkan sudut pandang dari tulisan-tulisan tersebut adalah otentik; sedangkan tugas membaca untuk mencari ide utama dari tiap-tiap paragraf adalah tidak otentik. Asesmen otentik dapat berupa berbagai metode asesmen yang dapat mencerminkan berbagai aktivitas proses belajar, hasil belajar, motivasi, maupun sikap.

Orientasi pendidikan kontemporer yang menekankan pembentukan kompetensi memberi peluang sangat luas bagi asesmen non-tes yang bersifat otentik seperti asesmen portofolio, asesmen kinerja, projek, evaluasi diri, dan esai. Asesmen otentik seringkali disebut dengan non-tes.

\section{Asesmen Portofolio}

Asesmen portofolio adalah asesmen proses dan produk. Diantara pendekatan asesmen sejenis, asesmen portofolio disebut sebagai pendekatan paling komprehensif karena mampu mengumpulkan informasi secara berkelanjutan dan melibatkan asesmen lain seperti asesmen kinerja, projek, dan bahkan tes (objektif maupun esai, bila diperlukan). Asesmen portofolio adalah salah satu asesmen otentik karena salah satu cirinya adalah adanya suatu proses penilaian yang berkelanjutan (on-going) yang dimulai dari awal hingga mencapai suatu produk karya tertentu. Keseluruhan proses yang terjadi merupakan suatu portofolio pada mana penilaian dilakukan.

Asesmen portofolio memiliki tiga elemen utama, yaitu:

a. Sampel Karya Siswa yang menunjukkan perkembangan belajarnya dari waktu ke waktu. Sampel tersebut dapat berupa tulisan/karangan, audio atau video, laporan, problem matematika, maupun eksperimen.

b. Evaluasi Diri, yaitu suatu analisis terhadap sikap dan proses belajar siswa, dimana informasi tersebut dapat digunakan untuk meningkatkan perkembangan dan proses belajar yang berkelanjutan. 
Dalam asesmen portofolio, evaluasi diri merupakan komponen yang sangat penting. O'Malley dan Valdez Pierce bahkan mengatakan bahwa 'self-assessment is the key to portfolio'. Hal ini disebabkan karena melalui evaluasi diri siswa dapat membangun pengetahuannya serta merencanakan dan memantau perkem-bangan belajarnya;

c. Kriteria Penilaian yang Jelas dan Terbuka, bukan menjadi 'rahasia' guru. Adanya kriteria penilaian terkait dengan tujuan pembelajaran. Karena itu, harus jelas tujuan dan ranah belajar yang hendak dicapai. Dengan asesmen portofolio dimungkinkan menetapkan lebih dari satu ranah secara bersama-sama dan multidimensi. yaitu asesmen pada proses maupun konstruk. Proses melibatkan siswa dan guru yang bekerja secara kolaboratif dalam membangun portofolio. Konstruk adalah folder, binder, atau pun kotak dimana bahan-bahan asesmen dikumpulkan.

\section{Asesmen Kinerja}

Asesmen kinerja adalah suatu prosedur yang menggunakan berbagai bentuk tugas-tugas untuk memperoleh informasi tentang apa dan sejauhmana yang telah dipelajari siswa. Asesmen kinerja mensyaratkan siswa menggunakan pengetahuan dan keterampilannya untuk menunjukkan sejauhmana siswa tersebut telah mencapai suatu target belajar. Pemantauan didasarkan pada kinerja (performance) yang ditunjukkan dalam menyelesaikan suatu tugas atau permasalahan yang diberikan. Hasil yang diperoleh merupakan suatu hasil dari unjuk kerja tersebut.

Asesmen kinerja adalah penelusuran produk dalam proses. Artinya, hasil-hasil kerja yang ditunjukkan siswa selama proses belajarnya digunakan sebagai basis untuk dilakukan suatu pemantauan mengenai perkembangan dan hasil belajar siswa.

Terdapat tiga komponen utama dalam asesmen kinerja, yaitu tugas kinerja (performance task), rubrik performansi (performance rubrics), dan cara penilaian (scoring guide). Tugas kinerja adalah suatu tugas yang berisi topik, standar tugas, deskripsi tugas, dan kondisi penyelesaian tugas. Rubrik performansi merupakan suatu rubrik yang berisi komponen-komponen suatu performansi ideal, dan deskriptor dari setiap komponen tersebut. Cara penilaian kinerja ada tiga, yaitu (1) holistic scoring adalah yaitu 
pemberian skor berdasarkan impresi penilai secara umum terhadap suatu kinerja; (2) analytic scoring, yaitu pemberian skor terhadap sejumlah komponen yang berkontribusi terhadap suatu kinerja. Apabila kinerja yang dinilai adalah suatu komposisi (karangan) maka komponen-komponennya adalah seperti tatabahasa, isi, dan organisasi tulisan; dan (3) primary traits scoring, yaitu pemberian skor berdasarkan beberapa sifat khusus dari tugas kinerja yang diberikan. Misalnya, bila komposisi yang dinilai berjenis argumentatif, maka penilaian dilakukan terhadap, antara lain berapa argumen yang digunakan dan sejauhmana argumen tersebut tepat pemakaiannya

\section{Masalah Subjektivitas Penilaian dalam Pembelajaran Kontekstual}

Isu subjektivitas terutama dalam penilaian pembelajaran yang bersifat terbuka dan berpusat pada siswa seperti pembelajaran kontekstual seringkali menjadi perdebatan. Ada pihak yang mengatakan bahwa hasil penilaian terhadap tugas, projek, portofolio, dan sebagainya, rentan dari segi validitas dan reliabilitas penilaian. Bagaimana mungkin, menurut pendapat ini, memban-dingkan dua siswa dari portofolio masing-masing, sementara portofolio mereka berisi hal-hal yang berbeda.

Pembelajaran Kontekstual adalah upaya untuk meningkatkan kinerja dan pemberdayaan siswa. Untuk tujuan ini, sangatlah sulit bila dilakukan dengan menggunakan tes-tes objektif (yang sama untuk semua siswa). Dan, perlu disadari bahwa pendidikan bukanlah untuk membandingkan satu siswa dengan yang lainnya, melainkan bertujuan untuk menghasilkan lulusan yang berkualitas tinggi, dengan kata lain, seorang siswa yang berhasil bukanlah karena dia mampu 'mengalahkan' saingan-saingannya, melainkan karena dia memiliki kompetensi yang tinggi dan dapat diandalkannya untuk menyongsong masa depannya.

Namun demikian, subjektivitas dalam diri penilai sendiri tidak dapat dihindarkan dalam asesmen non-tes. Suatu contoh, seorang guru yang terlalu banyak mengoreksi karangan cepat merasa lelah sehingga tidak cermat lagi dalam membaca tulisan siswa.

\section{Refleksi Pembelajaran Kontekstual}

Refleksi adalah cara berfikir tentang apa yang baru dipelajari atau berpikir ke belakang tentang apa-apa yang sudah kita lakukan di masa yang lalu. Refleksi merupakan gambaran terhadap kegiatan atau 
pengetahuan yang baru saja diterima. Siswa mengendapkan apa yang baru dipelajarinya sebagai struktur pengetahuan yang baru, yang merupakan pengayaan atau revisi dari pengetahuan sebelumnya. Refleksi merupakan respon terhadap kejadian, aktivitas, atau pengetahuan yang baru diterima. Misalnya ketika pelajaran berakhir, siswa merenung "Kalau begitu, cara saya menyimpan file selama ini salah, ya! Mestinya, dengan cara yang baru dipelajari ini, file computer saya lebih tertata."

Pengetahuan yang bermakna diperoleh dari proses. Pengetahuan yang dimiliki siswa diperluas melalui konteks pembelajaran, kemudian diperluas sedikit demi sedikit. Guru membantu siswa membuat hubungan antara pengetahuan yang dimiliki sebelumnya dengan pengetahuan yang baru. Dengan begitu siswa merasa memperoleh sesuatu yang berguna bagi dirinya tentang apa yang harus dipelajari.

Proses refleksi yang harus dilakukan oleh guru berupa : (1) pernyataan langsung tentang apa-apa yang diperoleh pada hari itu, (2) catatan atau jurnal di buku siswa, (3) kesan dan saran siswa mengenai pembelajaran hari itu, (4) diskusi, (5) hasil karya, dan (6) cara-cara lain yang ditempuh guru untuk mengarahkan siswa kepada pemahaman mereka tentang materi yang dipelajari.

Contoh perintah guru yang menggambarkan kegiatan refleksi adalah sebagai berikut: (1) bagaimana pendapatmu mengenai kegiatan hari ini, (2) hal-hal baru apa yang kalian dapatkan melalui kegiatan hari ini,(3) catatlah hal-hal penting yang kalian dapatkan ! (4) buatlah komentar di buku catatanmu tentang pembelajaran hari ini,(5) mungkinkah ketrampilan yang kalian pelajari hari ini kalian terapkan di rumah?

\section{Kesimpulan}

1. Pembelajaran Kontekstual adalah strategi pembelajaran yang menghubungkan antara konten pelajaran dengan situasi kehidupan nyata, dan mendorong siswa mengaitkan antara pengetahuan dan pengalaman yang didapatnya di sekolah dengan kehidupannya sebagai anggota keluarga, warganegara, dan dunia kerja.

2. Alasan perlu diterapkannya pembelajaran kontekstual adalah : (1) Sebagian besar waktu belajar sehari-hari di sekolah masih didominasi kegiatan penyampaian pengetahuan oleh guru, sementara siswa "dipaksa" memperhatikan dan menerimanya, 
sehingga tidak menyenangkan dan memberdayakan siswa (2) Materi pembelajaran bersifat abstrak-teoritis-akademis, tidak terkait dengan masalah-masalah yang dihadapi siswa sehari-hari di lingkungan keluarga, ma-syarakat, alam sekitar dan dunia kerja.(3) Penilaian hanya dilakukan dengan tes yang menekankan pengetahuan, tidak menilai kualitas dan kemampuan belajar siswa yang autentik pada situasi yang autentik. (4) Sumber belajar masih terfokus pada guru dan buku. Lingkungan sekitar belum dimanfaatkan secara optimal

3. Model pembelajaran yang merupakan aplikasi pembelajaran kontekstual antara lain model pembelajaran langsung (direct instruction), pembelajaran koperatif (cooperative learning), pembelajaran berbasis masalah ( problem based learning)

4. Strategi dalam melakukan pembelajaran kontekstual yang diakronimkan menjadi REACT, yaitu: relating, experiencing, applying, cooperating, dan transferring

5. Model penilaian dalam pembelajaran kontekstual menggunakan system penilaian yang disebut Authentic Assesment (Penilaian yang sebenarnya). Prinsip dan ciri yang dipakai dalam penilaian autentik adalah sebagai berikut: (1) Harus mengukur semua aspek pembelajaran: proses, kinerja, dan produk, (2) dilaksanakan selama dan sesudah proses pembelajaran berlangsung, (3) menggunakan berbagai cara dan berbagai sumber, (4) tes hanya salah satu alat pengumpul data penilaian, (5) tugas-tugas yang diberikan kepada siswa harus mencerminkan bagian-bagian kehidupan siswa yang nyata setiap hari, mereka harus dapat menceriterakan pengalaman atau kegiatan yang mereka lakukan setiap hari, (6) penilaian harus menekankan kedalaman pengetahuan dan keahlian siswa, bukan keluasannya (kuantitas) 
Konsep Pembelajaran Kontekstual, Oleh: Hamam

\section{DAFTAR RUJUKAN}

Bond, L. P. (2005). Using Contextual Instruction to Make Abstract Learning Concrete. Copyright 2005. Association for Career and Technical Education, printed on $15^{\text {th }}$ July 2005.

Clifford, M. and Wilson, M. (2000). 'Professional Learning and Student's Experiences: Lesson Learned from Implementation'. Educational Brief . No. 2 December 2000. Texas Collaborative for Teaching Excellence. (2005). REACT Strategy. Printed on $15^{\text {th }}$ July 2005.

Depdiknas. (2002). Pendekatan Kontekstual. Jakarta : Depdiknas

Depdiknas. (2002). Pembelajaran dan Pengajaran Kontekstual. Jakarta : Depdiknas

Ibrahim, M. \& Nur, M. (2000). Pembelajaran Berdasarkan Masalah, Surabaya: Unesa-University Press

Ibrahim, M. \& Nur, M., dkk. (2000). Pembelajaran Koperatif. Surabaya : Unesa-University Press

Johnson, Elaine B. 2002. Contextual Teaching and Learning: What is is and why it's here to stay. United states of America: Corwin Press, Inc.

Joyce, B. \& Weil, M. (1996). Models of Teaching, $5^{\text {th }}$ Edition. Boston: Allyn \& Bacon.

Kardi, S. \& Nur, M. (2000). Pengajaran Langsung. Surabaya :Unesa-University Press.

Nitko, A.J. (1996). Educational Assessment of Students. $2^{\text {nd }}$ Edition. New Jersey: Merrill.

Nurhadi, dkk., 2004. Kontekstual dan Penerapannya dalam KBK, Malang :Penerbit Universitas Negeri Malang.

Paris, S. G. \& Winograd, P. (2005). The Role of Self-Regulated Learning in Contextual Teaching: Principles and Practices for Teacher Preparation (artikel download).

Popham, W.J. (1995). Classroom Assessment, What Teachers Need to Know. Boston: Allyn and Bacon.

Salvia, J. \& Ysseldyke, J.E. (1996). Assessment. $6^{\text {th }}$ Edition. Boston: Houghton Mifflin Company.

Rolheiser, C. \& Ross, J. A. (2005) Student Self-Evaluation: What Research Says and What Practice Shows. Internet download. 